\title{
Ultrastructure of a Marine Thiobacillus
}

\author{
By J. R. MURPHY,* A. E. GIRARD AND R. C. TILTON \\ University of Connecticut Health Center, Farmington, Connecticut, U.S.A.
}

(Received I9 March 1974; revised 27 May 1974)

\begin{abstract}
SUMMARY
The ultrastructure of Thiobacillus sp. IV-85 was examined by thin section and freeze-etch techniques. The morphology of this marine isolate was similar to that of terrestrial species of Thiobacillus. Decline phase preparations showed a marked degeneration of internal organization. Membrane vesicles, characteristically bound by a trilaminar membrane, were observed only in preparations of decline phase cells. The examination of freeze-etched preparations of both first and second log phase organisms showed membrane-bound polyhedral inclusion bodies in intact cells and a characteristically rippled envelope.
\end{abstract}

\section{INTRODUCTION}

The isolation of thiobacilli from the marine environment has been periodically reported (Tilton, Cobet \& Jones, I967; Adair \& Gunderson, 1969). In general, these isolates were regarded as being marine counterparts to previously described fresh-water or terrestrial species of Thiobacillus. Many are acidophilic and are able to survive in extreme environments. Consequently, some members of the genus have been examined electron-microscopically for possible structural adaptation. The ultrastructure of Thiobacillus thiooxidans (Mahoney \& Edwards, 1966; Shively, Decker \& Greenawalt, 1970), T. novellus (Kocur, Martinec \& Mazanek, 1968; Shively et al. 1970), Thiobacillus sp. A2 (Taylor \& Hoare, 1969; Shively et al. 1970), T. thioparus, $T$. intermedius, $T$. neapolitanus and $T$. denitrificans (Shively et al. I970) have been described. The only report concerned with the ultrastructure of a marine Thiobacillus species has been that of Tilton, Stewart \& Jones (1967).

The freeze-etching technique has been widely used as an adjunct to thin sectioning for the study of the envelope in Gram-negative bacteria (Remsen \& Lundgren, I966; Van Caseele \& Lees, 1969; Bayer \& Remsen, 1970; Nanninga, 1970; De Voe, Costerton \& MacLeod, I97I). This technique, as first described by Steere (1957) and refined by Moor (I964), produces 'artefact free' (i.e. artefacts due to chemical fixation and dehydration) replicas of preparations.

Recently, Murphy, Kornfeld \& Tilton (1971, 1972) have described biphasic utilization of thiosulphate and the effect of tetrathionate accumulation on the growth of Thiobacillus sp. IV-85. This strain, which was isolated from the open ocean, appears to be a unique species of Thiobacillus (Murphy, unpublished observations). The ultrastructure of first and second $\log$ phase and decline phase cells of this isolate were examined by thin sectioning and freezeetching, to determine the nature of structural alterations that might be associated with different stages of the growth cycle.

\footnotetext{
* Present address: Department of Microbiology and Molecular Genetics, Harvard Medical School, Boston, Massachusetts 02 I I 5, U.S.A.
} 


\section{METHODS}

Thiobacillus sp. IV- 85 was grown on the thiosulphate-sea water salts medium previously described (Murphy et al. 197I). Bacteria were harvested by centrifugation at I $8000 \mathrm{~g}$ for Io min at $4{ }^{\circ} \mathrm{C}$ and all subsequent steps were carried out at this temperature. The pellet was resuspended in sterile synthetic sea water (Lyman \& Fleming, 1940). Accumulated elemental sulphur was removed by centrifugation at $1000 \mathrm{~g}$ for $3 \mathrm{~min}$, after which the cell suspension was decanted and re-centrifuged. This centrifugation procedure was repeated four times, then a sample was removed and prepared for electron-microscope examination.

Bacteria were fixed in glutaraldehyde $(3 \%, \mathrm{v} / \mathrm{v})$ and osmium tetroxide $(2 \%, \mathrm{w} / \mathrm{v})$ in synthetic sea water. Fixation and washing procedures were performed at $4{ }^{\circ} \mathrm{C}$. The doubly fixed specimens were washed in saline $(0.9 \%, \mathrm{w} / \mathrm{v}, \mathrm{NaCl})$, dispersed in $\mathrm{I} \%(\mathrm{w} / \mathrm{v})$ melted agar and centrifuged at $8000 \mathrm{~g}$ for $10 \mathrm{~min}$. The resulting pellet was cut into small cubes (approx. $\mathrm{I} \mathrm{mm}^{3}$ ), dehydrated in increasing concentrations of ethanol, and embedded in Epon 8I 2 as described by Luft (196I).

Thin sections were cut, collected unsupported on 300-mesh copper grids, and stained with uranyl acetate followed by lead citrate (Reynolds, I963). Specimens were examined in a Hitachi HU-I I E-I electron microscope at an accelerating voltage of $75 \mathrm{kV}$.

Glutaraldehyde-fixed bacteria were examined following carbon-platinum shadowing. Bacteria were removed from the glutaraldehyde-synthetic sea water buffer by centrifugation and washed twice in distilled water containing $\mathrm{I} \%(\mathrm{w} / \mathrm{v})$ bovine serum albumin (BSA) and $3 \%(\mathrm{w} / \mathrm{v})$ glutaraldehyde. The bacteria were then resuspended in the BSA-glutaraldehyde buffer and dropped on to Formvar-supported carbon-coated 200-mesh copper grids. After drying, the grids were shadowed at an angle of approximately $30^{\circ}$ with platinum-carbon.

Bacteria were harvested for freeze-etching and replica preparation by centrifugation and, without prior fixation, the pellet was resuspended in sterile synthetic sea water. The bacteria were then frozen in Freon-22, stored in liquid nitrogen, and transferred into the Balzer apparatus (Moor, Mühlethaler, Waldner \& Frey-Wyssling, 1961) for freeze-fracturing and etching. Freeze-etching was performed as described by Moor \& Mühlethaler (1963). The replicas were exposed to $70 \%(\mathrm{v} / \mathrm{v}) \mathrm{H}_{2} \mathrm{SO}_{4}$ followed by $5 \cdot 25 \%$ (w/v) sodium hypochlorite solution to wash off adhering cell residues. The replicas were picked up on Formvar-coated grids and examined in the electron microscope.

\section{RESULTS}

\section{Shadow-cast preparations}

Thiobacillus sp. IV-85, a Gram-negative rod, is motile by means of a single polar flagellum (Fig. I). Early log phase cultures were found to be most actively motile.

\section{Thin section preparations}

Bacteria harvested at, or before, the time of $20 \%$ thiosulphate utilization were considered representative of first log phase. Electron micrographs of thin sections of these bacteria show that the polyhedral inclusion bodies (diameter approx. $100 \mathrm{~nm}$ ), characteristic of many thiobacilli, are in close association with the nuclear region along the central axis of the cell (Fig. 2). The ribosomes were discrete and well preserved. Thiobacillus sp. IV-85 has a typical multilayered envelope characteristic of Gram-negative bacteria.

Bacteria harvested after $70 \%$ thiosulphate utilization were used as second log phase cells. Their ultrastructure was essentially the same as first log phase cells. 


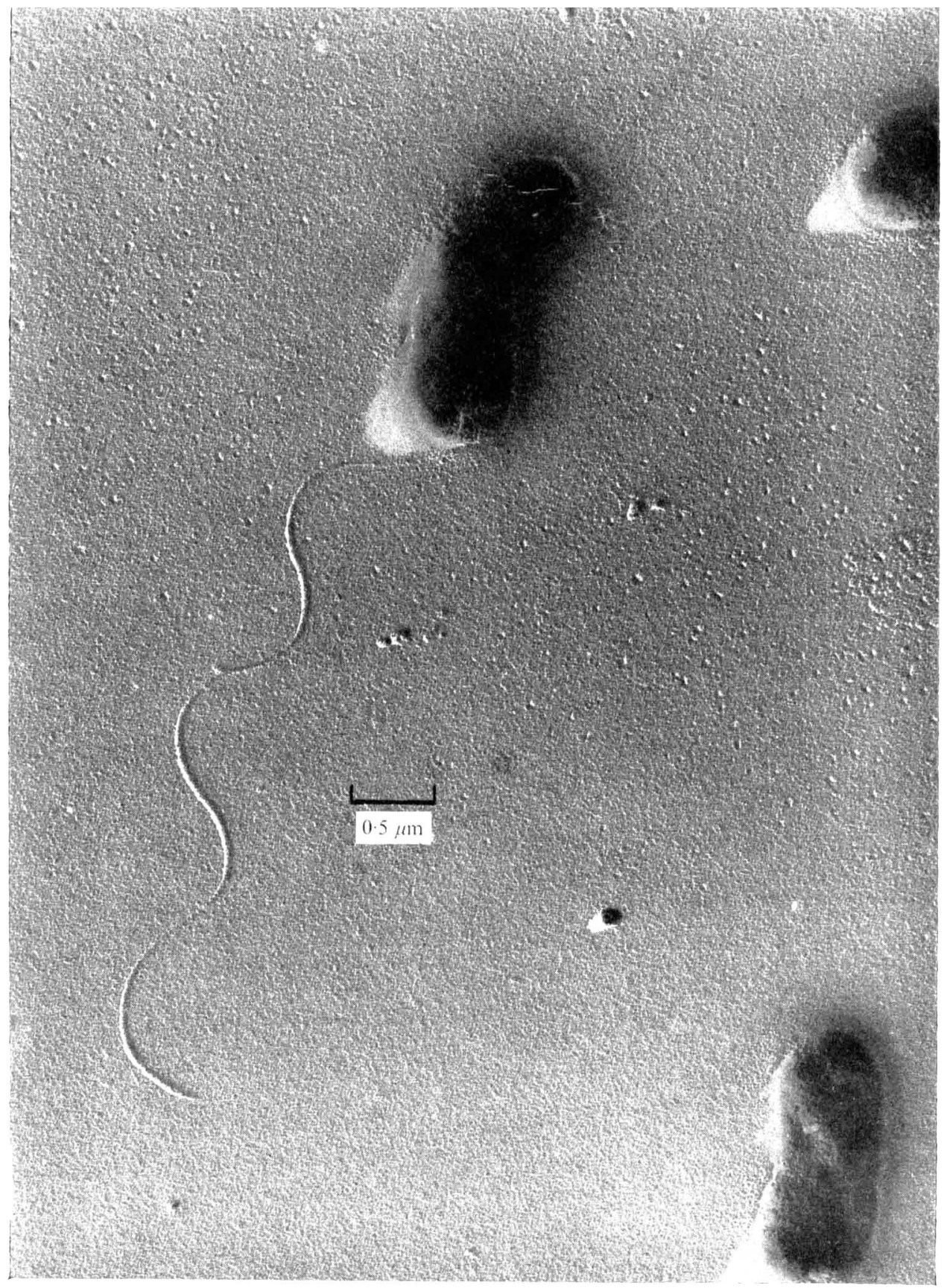

Fig. I. Shadowed preparation (platinum-carbon). A single polar flagellum can be seen. 


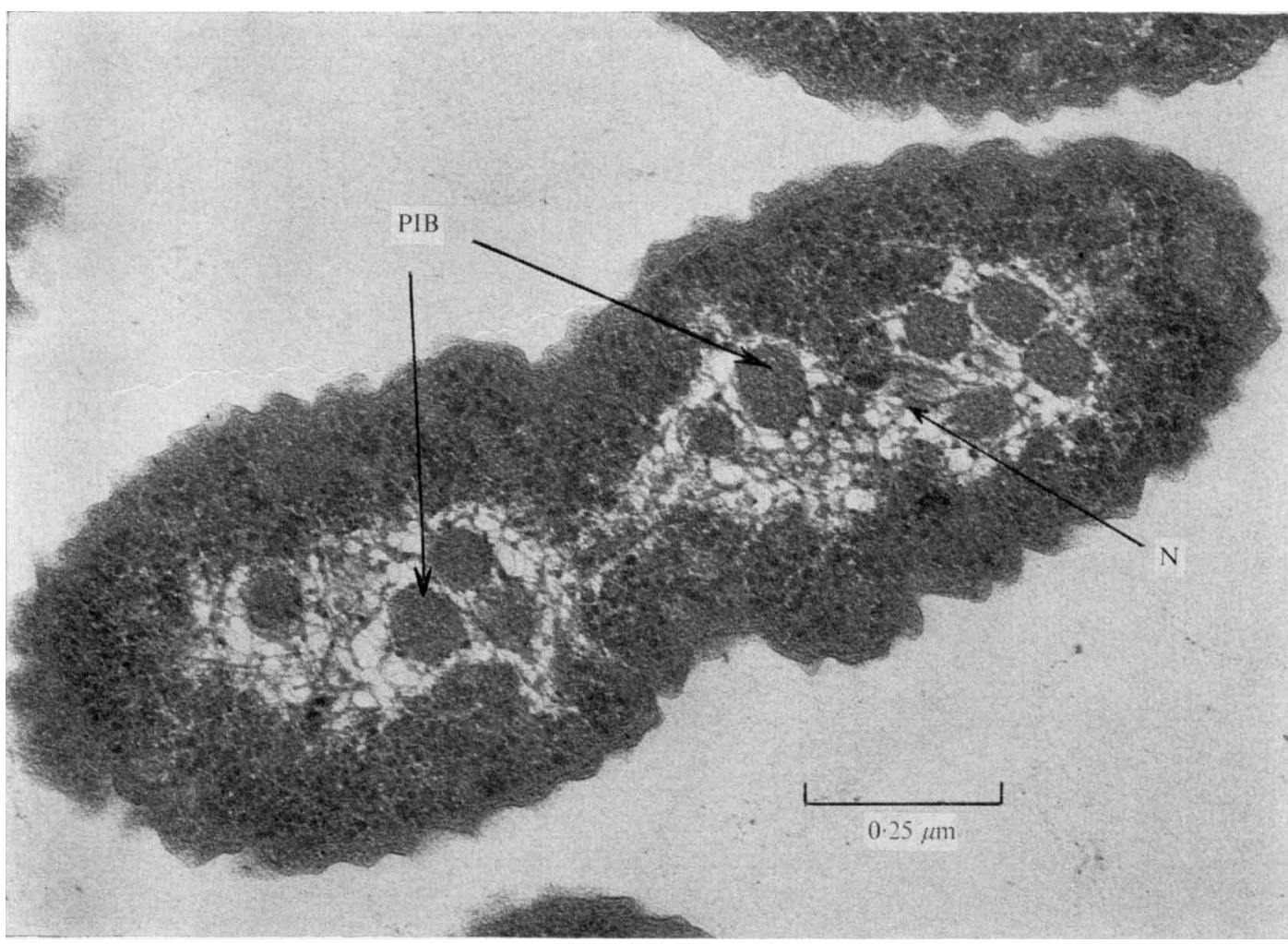

Fig. 2. Thin sections of early log phase cells, showing polyhedral inclusion bodies (PIB) associated with the nuclear region $(\mathrm{N})$.

Cytokinesis of Thiobacillus sp. IV-85 proceeds by an invagination of the entire envelope. No septum or plate was observed in any of the preparations examined.

The $\mathrm{pH}$ of the spent medium decreases rapidly after complete utilization of thiosulphate (Murphy et al. 1972). Bacteria remain viable in the absence of thiosulphate for approximately 5 days. Thin sections showed that decline phase bacteria differed markedly from first and second log phase bacteria. The internal structure and organization degenerated (Fig. 3). Polyhedral inclusion bodies are rarely observed in these preparations. Extracellular membrane vesicles were only observed in decline phase cells. These vesicles (Fig. 3) are bordered by a trilaminar membrane and are approximately $100 \mathrm{~nm}$ in diameter.

Freeze-etched preparations. First and second log phase and decline phase bacteria of Thiobacillus sp. IV-85 were examined by freeze-etching. The rippled appearance of the envelope seen in thin sections is also observed in freeze-etch preparations (Fig. $4 a$ ). The outer layer of the envelope is not easily demonstrated, since it seems to fracture only in short planes. In addition, it is easy to confuse the outer layer with the eutectic shell produced by the etching process. This observation has been made in other Gram-negative bacteria (Fiil \& Branton, 1969; Bayer \& Remsen, 1970; De Voe et al. 197I). De Voe et al. (I97I) examined a marine bacterium and presented evidence that only one cleavage plane occurred in the wall, between the cytoplasmic membrane and the external eutectic shell. They further noted that wall layers are seen in the 'step' between the cleavage plane of the cytoplasmic membrane and that of the wall, but they do not significantly deflect the actual cleavage in 


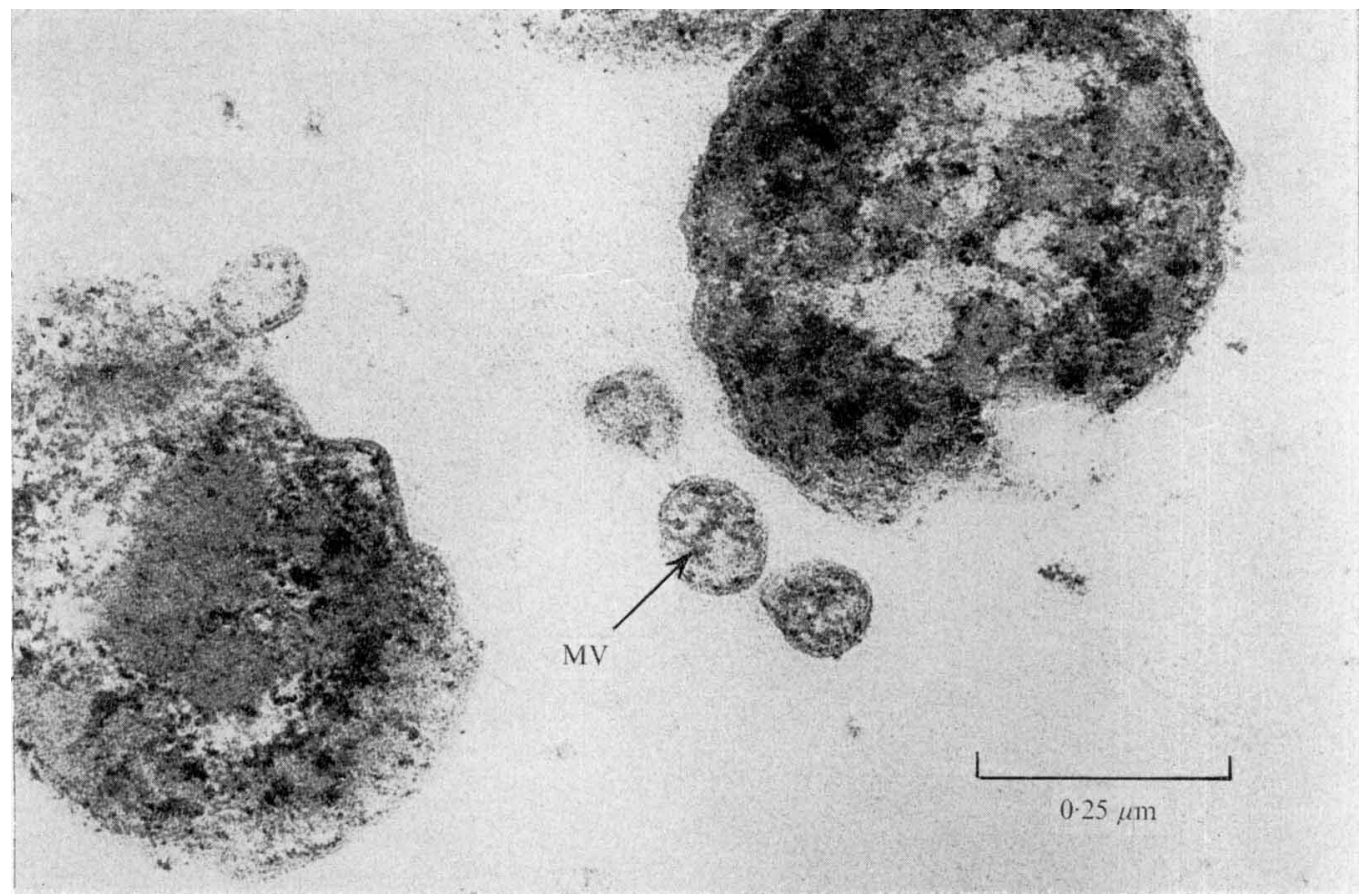

Fig. 3. Thin section preparation of decline phase cells showing appearance of extracellular membrane vesicles (MV) and a marked degeneration of the internal organization.

the envelope. In Thiobacillus sp. IV-85, cleavage of the envelope exposed a particle studded surface at the level of the cytoplasmic membrane (Fig. $4 a, b$ ). The particles were very dense and not typical of the disperse particles often observed on biological membranes. This may represent the middle layer seen in thin sections. Rodlets seen in freeze-etched preparations of Ferrobacillus ferrooxidans (Remsen \& Lundgren, 1966) were not observed in Thiobacillus sp. IV-85. Similar rodlets were reported by Fiil \& Branton (I969) in Escherichia coli but were considered to be artefacts. Cross-cleavage of the cytoplasm revealed larger, more discrete particles and polyhedral inclusion bodies (Fig. $4 b, c$ ). Polyhedral inclusion bodies at different levels in the cytoplasm are seen in Fig. $5(a),(b)$. The convex cleavage of the cytoplasm revealed inclusion bodies which were (i) cleaved along the fracture plane, (ii) partially exposed, and (iii) fully exposed. The fully exposed polyhedral inclusion bodies appeared to be bound by a smooth membrane. Fig. $5(b)$ shows an inclusion body in which etching has removed the contents, thereby revealing a smooth concave membrane surface.

Decline phase bacteria had extracellular membrane vesicles approximately $100 \mathrm{~nm}$ in diam (Fig. $5 c$ ). The cross-cleavage reveals a fine granular interior.

\section{DISCUSSION}

The ultrastructure of the marine Thiobacillus sp. IV-85 by thin sectioning is similar to that of terrestrial species of thiobacilli which have been previously described (Mahoney \& Edwards, 1966; Kocur et al. 1968; Taylor \& Hoare, 1969; Shively et al. 1970). The organization and appearance of the envelope (outer layer, middle layer and cytoplasmic membrane) is the same as that described for other Gram-negative bacteria (Murray, Steed \& Elson, 

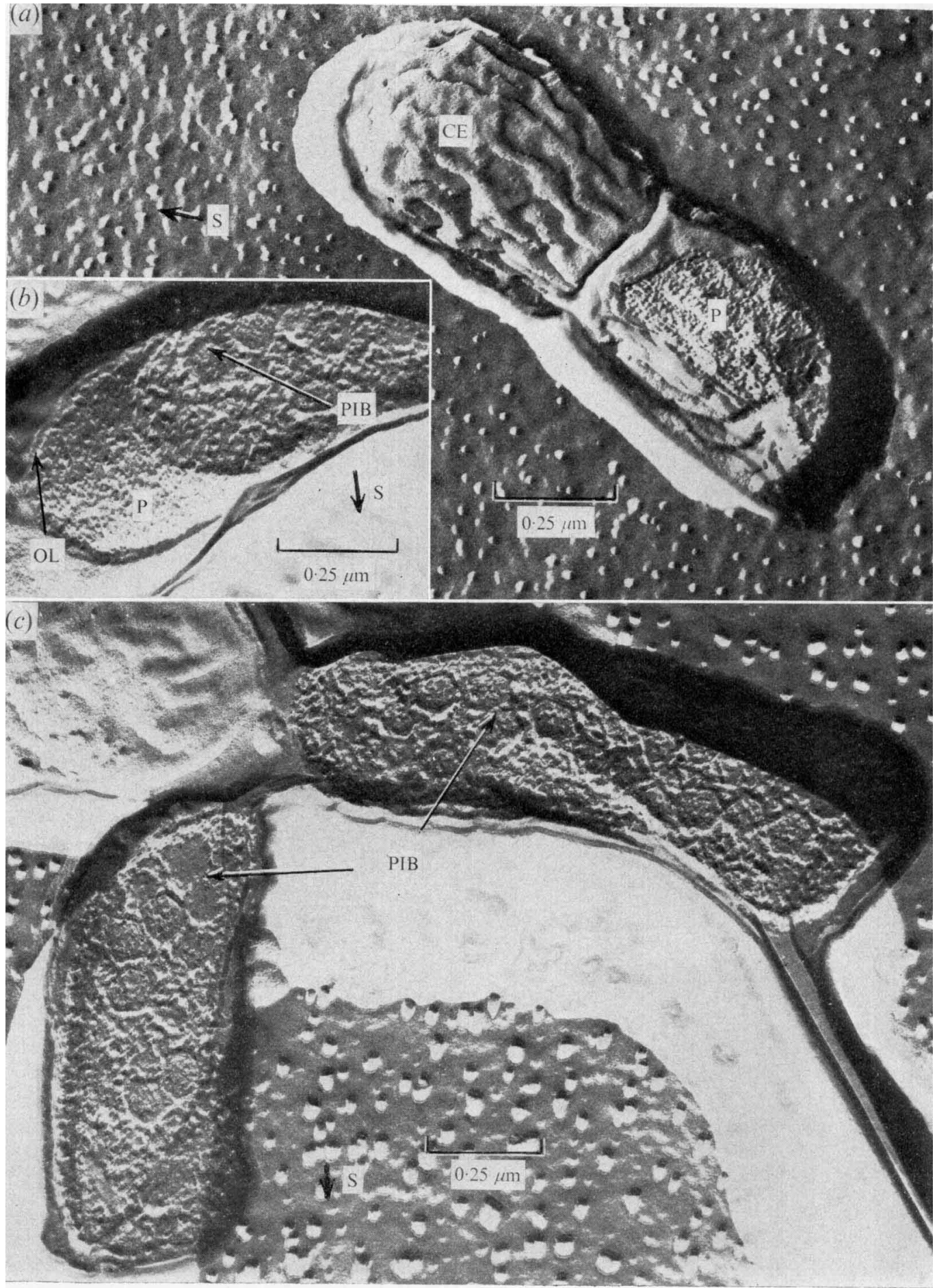

Fig. 4. Freeze-etch preparations of early log phase cells. (a) Rippled surface of the cell envelope (CE). (b) Outer layer (OL) and particle layer (P) of the cell envelope, and polyhedral inclusion bodies (PIB). (c) Numerous polyhedral inclusion bodies (PIB). S, shadowed side. 


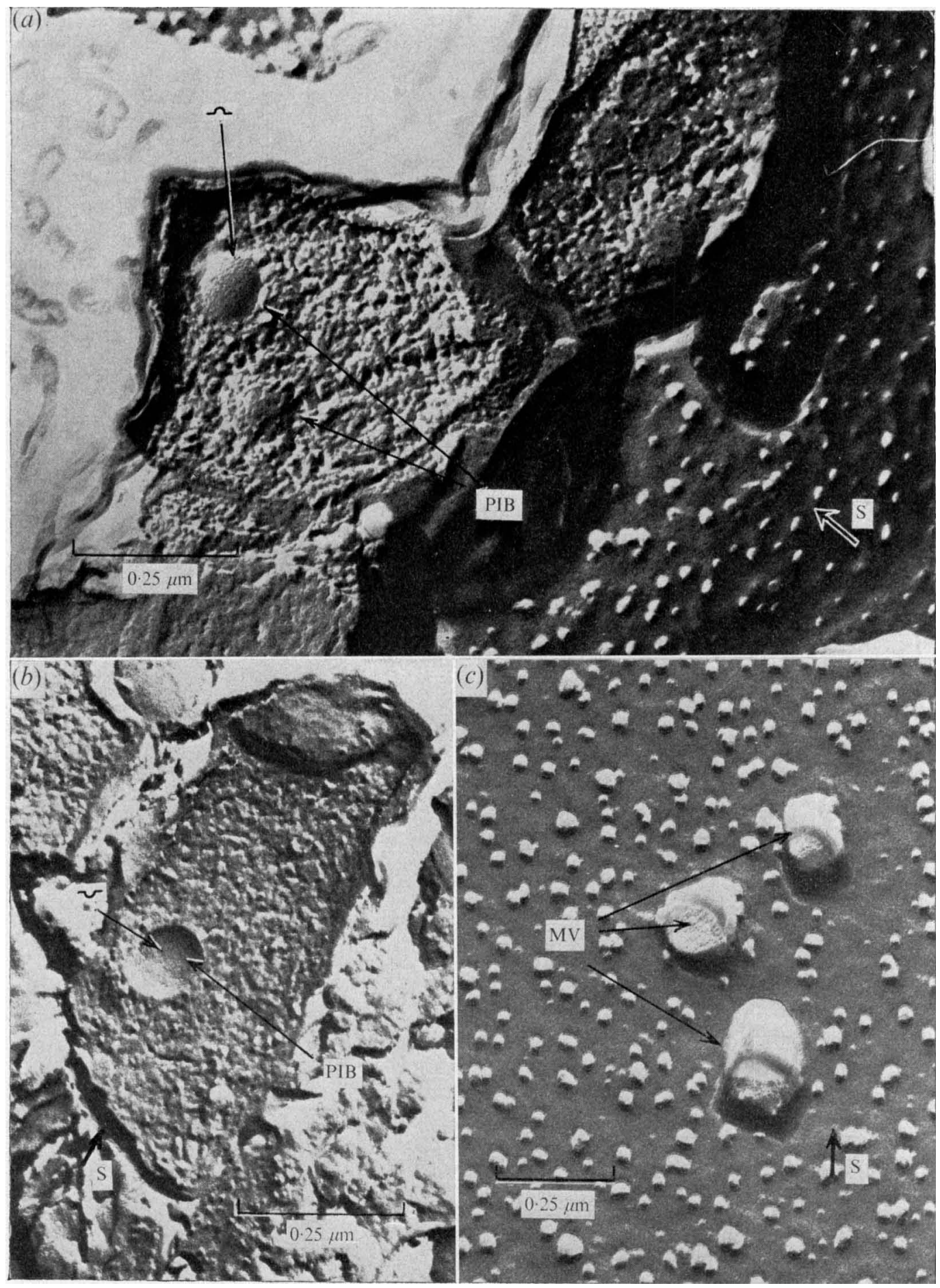

Fig. 5. Freeze-etch preparations of late log phase ( $a$ and $b$ ) and decline phase $(c)$ cells. (a) Crosscleavage of polyhedral inclusion bodies (PIB) at different levels in the cytoplasm; $\sim$, convex cleavage. (b) A concave membrane surface ( $\sim$ ) of a PIB. (c) Extracellular membrane vesicles (MV) in decline phase cell preparations. S, shadowed side. 
I965; De Petris, 1967). In addition, the envelope of Thiobacillus sp. IV-85 shows the typical rippled appearance that has been observed in other thiobacilli (Mahoney \& Edwards, I966; Taylor \& Hoare, 1969; Shively et al. 1970). Shively et al. (1970) suggested that the rippled envelope may be characteristic, rather than an artefact due to changes in the osmotic conditions during fixation. The rippled envelope of Thiobacillus sp. IV- 85 seen in freeze-etched preparations provides direct evidence that this is an authentic characteristic of this isolate.

Polyhedral inclusion bodies have been reported in many of the thiobacilli (Mahoney \& Edwards, I966; Shively et al. 1970), ferrobacilli (Dugan \& Lundgren, 1965), Nitrobacter agilis (Murray \& Watson, I965), and many of the blue-green algae (Gault \& Conti, I969; Wolk, 1973). Shively et al. (1970) have observed at low and intermediate magnification a suggestion of a polyhedral inclusion body-limiting membrane in thin-section preparations of T. neapolitanus. Freeze-etching of Thiobacillus sp. IV-85 has revealed a smooth membrane surface, both external and internal, of polyhedral inclusion bodies in situ. The freeze fracture of bilayer membranes is now known to form cleavage planes in the hydrophobic region, exposing a particle-studded surface (Pinto Da Silva \& Branton, 1970). Recently, Shively, Ball, Brown \& Saunders (1973 $a$ ) and Shively, Ball \& Kline (1973b) have demonstrated that the polyhedral inclusion bodies of $T$. neapolitanus were bound by an atypical single layer membrane, $0.35 \mathrm{~nm}$ thick, and contained ribulose diphosphate carboxylase activity. They have renamed the polyhedral inclusions of $T$. neapolitanus as carboxysomes. The smooth polyhedral inclusion membrane observed in freeze-etched preparations of Thiobacillus $\mathrm{sp}$. IV-85 is atypical of bilayer membranes and adds additional support to the single layer membrane described by Shively et al. ( $1973 b$ ) for carboxysomes of $T$. neapolitanus. The ribulose diphosphate carboxylase activity in polyhedral inclusion bodies of Thiobacillus sp. IV-85 has not been determined.

We acknowledge the excellent technical assistance rendered by Mrs Barbara H. Jacius of the University of Connecticut Health Center. This investigation was supported by Public Health Service pre-doctoral fellowship No. PR-05678-03 to J. R. M. We thank Dr J. Shively for communicating his results before publication, and Dr Richard L. Weiss for reading the manuscript and for his suggestions and criticisms.

\section{REFERENCES}

Adair, W. F. \& Gunderson, K. (1969). Chemoautotrophic sulfur bacteria from the marine environment. I. Isolation, cultivation and distribution. Canadian Journal of Microbiology r5, 345-353.

BAYER, M. E. \& REMSEN, C. C. (I970). Structure of Escherichia coli after freeze-etching. Journal of Bacteriology ror, 304-313.

DE PETRIS, S. (1967). Ultrastructure of the cell wall of Escherichia coli and chemical nature of its constituent layers. Journal of Ultrastructure Research 9r, 45-83.

De Voe, I. W., Costerton, J. W. \& MacLeod, R. A. (I97I). Demonstration by freeze-etching of a single cleavage plane in the cell wall of a Gram negative bacterium. Journal of Bacteriology 106, 659-67I.

Dugan, P. R. \& Lundgren, D. G. (1965). Energy supply for the chemoautotroph Ferrobacillus ferrooxidans. Journal of Bacteriology 89, 825-834.

Fill, A. \& Branton, D. (1969). Changes in the plasma membrane of Escherichia coli during magnesium starvation. Journal of Bacteriology $98,1320-1327$.

GAult, E. \& Contı, S. F. (I969). Ultrastructure of blue green algae. Journal of Bacteriology 97, I486-1493.

Kocur, M., Martinec, T. \& MAzANEK, K. (I968). Fine structure of Thiobacillus novellus. Journal of General Microbiology 52, 343-345.

LuFT, J. H. (1961). Improvements in epoxy resin embedding methods. Journal of Biophysical and Biochemical Cytology 9, 407-4I I.

Lyman, J. \& Fleming, R. H. (1940). Composition of sea water. Journal of Marine Research 3, I34-I46. 
Mahoney, R. P. \& Edwards, M. R. (1966). Fine structure of Thiobacillus thiooxidans. Journal of Bacteriology 92, 487-495.

Moor, H. (I964). Die Gefrierfixation lebender Zellen und ihre Anwendung in der Elektronenmikroskopie. Zeitschrift für Zellforschung 62, 546-580.

Moor, H. \& Mühlethaler, K. (1963). Fine structure in frozen-etched yeast cells. Journal of Cell Biology I7, 609-628.

Moor, H., Mühlethaler, K., Waldner, H. \& Frey-Wyssling, A. (I96I). A new freezing ultramicrotome. Journal of Biophysical and Biochemical Cytology ro, I-I3.

Murphy, J. R., Kornfeld, J. M. \& Tilton, R. C. (1971). Biphasic thiosulphate utilization by a marine Thiobacillus. Journal of General Microbiology 68, $231-233$.

Murphy, J. R., Kornfeld, J. M. \& Tilton, R. C. (I972). Effect of tetrathionate on the growth of a marine Thiobacillus. Journal of General Microbiology 73, 339-343.

Murray, R. G. E., Steed, P. \& Elson, H. E. (1965). The location of the mucopeptide in sections of the cell wall of Escherichia coli and other Gram negative bacteria. Canadian Journal of Microbiology Ir, 547-560.

Murray, R. G. E. \& WATSON, S. W. (1965). Structure of Nitrosocystis oceanus and comparison with Nitrosomas and Nitrobacter. Journal of Bacteriology 98, 824-836.

NANNINGA, N. (1970). Ultrastructure of the cell envelope of Escherichia coli B after freeze-etching. Journal of Bacteriology I01, 297-303.

Pinto DA Silva, P. P. \& BRanton, D. (1970). Membrane splitting in freeze-etching. Covalently bound Ferritin as a membrane marker. Journal of Cell Biology 45, 598-605.

RemSEN, C. C. \& LundGRen, D. G. (1966). Electron microscopy of the cell envelope of Ferrobacillus ferrooxidans prepared by freeze-etching and chemical techniques. Journal of Bacteriology 92, 1765-I 77 I.

REYNOLDS, E. S. (1963). The use of lead citrate at high $\mathrm{pH}$ as an electron opaque stain in electron microscopy. Journal of Cell Biology 17, 208-2 I2.

Shively, J. M., Ball, F., Brown, D. H. \& Saunders, R. E. (1973a). Functional organelles in procaryotes: polyhedral inclusions (carboxysomes) of Thiobacillus neapolitanus. Science, New York r82, 584-586.

Shively, J. M., BALl, F. L. \& Kline, B. W. (1973b). Electron microscopy of the carboxysomes (polyhedral bodies) of Thiobacillus neapolitanus. Journal of Bacteriology 116, 1405-141 I.

Shively, J. M., Decker, G. L. \& Greenawalt, J. W. (I970). Comparative ultrastructure of the thiobacilli. Journal of Bacteriology 94, I679-1683.

STEERE, R. L. (1957). Electron microscopy of structural details in frozen biological specimens. Journal of Biophysical and Biochemical Cytology 3, 45-60.

TAylor, B. \& HoARe, D. (1969). New facultative Thiobacillus and a re-evaluation of the heterotrophic potential of Thiobacillus novellus. Journal of Bacteriology 100, 487-497.

Tilton, R. C., Coзet, A. \& Jones, G. E. (1967). Significance and distribution of marine sulfur oxidizing bacteria. Canadian Journal of Microbiology $13,1521-1528$.

Tilton, R. C., Stewart, G. \& Jones, G. E. (1967). Characterization and ultrastructure of marine sulfur oxidizing bacteria. Canadian Journal of Microbiology 13, 1529-1536.

Van Caseele, L. \& Lees, H. (1969). The ultrastructure of autotrophically and heterotrophically grown Thiobacillus novellus. Canadian Journal of Microbiology 15, 65 I-654.

Wolk, C. P. (1973). Physiology and cytological chemistry of blue green algae. Bacteriological Reviews 37, 32-IOI. 